Univerzitetska misao - časopis za nauku, kulturu i umjetnost [ISSN: 1451-3870]

Vol. 17, str. 125-135, 2018 god., web lokacija gde se nalazi rad:http://um.uninp.edu.rs

Tematska oblast u koju se svrstava rad: Društvene i humanističke nauke / podoblast: Pedagogija Datum prijema rada: 25.05.2018. UDK: 37.06 Datum prihvatanja rada: 03.12.2018.

Originalan naučni rad

\title{
PEDAGOGICAL MEDIATION- MEDIA AS COMMUNICATION CONCEPT
}

\author{
Müedin Kahveci \\ Macedonia, Gostivar International VISION University \\ Gostivar, Macedonia \\ muhittin.kahveci@vizyon.edu.mk
}

\begin{abstract}
Apstrakt
A new effective model applied in education, the last years of pedagogical mediation process Model for the conflict resolution that allows young people to independently to develop their potential and realize their interests and needs.

Mediation - Mediation as a pedagogical process is very important to be implemented in the educational process especially peer mediation, that could be provided in front of safe schools. By implementing this model, training of teachers and the training of students we provide peace, security and essential would be non-violent conflict resolution, non-violent communication. The process of pedagogical mediation teaches all stakeholders in the school how to communicate among themselves which language to use encourages the maturation of the new mindset of understanding. This process is very important because it contributes to built a trustworthy interpersonal relationships that contribute much in terms of non-violent conflict resolution, successful and productive communication, improve school climate and improvement of the educational process.

The question is how and whether this pedagogical model is effectively implemented in secondary schools and whether it contributes to reducing conflict and are strengthened between human relations and communication skills. The success of implementing mediation not as pedagogical model in secondary schools is reduced to objective and subjective factors that this study gives a comprehensive description.
\end{abstract}

Keywords: mediation, education, violence, school, communication.

\section{PEDAGOŠKA MEDIJACIJA - MEDIJI KAO KONCEPT KOMUNIKACIJE}

\begin{abstract}
Novi efektivni model koji se primenjuje u obrazovanju, poslednjih godina pedagoškog procesa posredovanja Model rešavanja konflikta koji omogućava mladima da samostalno razvijaju svoje potencijale i realizuju svoje interese i potrebe.

Medijacija - Medijacija kao pedagoški proces veoma je važna za implementaciju u obrazovni proces, posebno vršnjačka medijacija, koja se može pružiti pred sigurnim školama. Primjenom ovog modela, obukom nastavnika i obukom studenata pružamo mir, sigurnost i bitno bi bilo nenasilno rješavanje sukoba, nenasilna komunikacija.
\end{abstract}


Proces pedagoškog posredovanja uči sve zainteresovane strane u školi kako da međusobno komuniciraju kojim jezikom se potiče sazrijevanje novog načina razmišljanja. Ovaj proces je veoma važan jer doprinosi izgradnji pouzdanih međuljudskih odnosa koji mnogo doprinose u smislu nenasilnog rješavanja sukoba, uspješne i produktivne komunikacije, poboljšanja školske klime i poboljšanja obrazovnog procesa.

Postavlja se pitanje kako i da li se ovaj pedagoški model efektivno primenjuje u srednjim školama i da li doprinosi smanjenju konflikta i ojačava se između ljudskih odnosa i komunikacijskih veština. Uspeh implementacije medijacije kao pedagoškog modela u srednjim školama svodi se na objektivne i subjektivne faktore koje ova studija daje sveobuhvatan opis.

Ključne riječi: medijacija, obrazovanje, nasilje, škola, komunikacija.

\section{INTRODUCTION}

The cornerstone of every society is the education system because it helps in raising future generations without prejudice, so they should be in condition of building a vibrant state.The education of future citizens begins very early, in the home with the family and then in the pre-school institutions, primary and secondary schools. All countries in the world tend to have quality education, education that will provide knowledge and skills, education that will enable good educational and upbringing for future generations.

In the Republic of Macedonia, the last years in education are being invested efforts for the democratization of educational institutions, all in its shape of a common life in which the principles of equality of rights apply. One of the most important segments for the smooth and successful realization of the entire educational and educational process is to reduce conflicts in schools by developing more tolerant relationships in educational institutions, by developing models through which they themselves students will be equal members of the collective through the freedom to participate, resolving problems, expressing an opinion and accepting responsibility.

The school's internal relations are very important to secure quality and effective education. School climate, culture and communication interactions are the most important factors that influence and contribute to the successful functioning of an educational institution.

Communication is the regulator of the entire teaching process, not just for the educational part, but also for the educators. It is an important factor for the development of a person, because through communication educators create conditions for the socialization of a person (respecting the others) at the same time allows individualization, because the significance of individual differences, abilities and motives. Throughout the process of communication each student has the opportunity to express his views and values, as well as convictions.

When we are mentioning the context of schools, there is no more important goal for the participants in the communication as it is mutual understanding and exchange that connect them. It's one of the the rare fields where the obstacles in the age, position, and title appear. It's a field where are all equal and have same rights, because no matter who the participants in the communication, children, adults, parents, teachers, directors ... they are only interlocutors. 
A new effective model that has been applied in education in recent years is the process of pedagogical mediation - a model for resolving conflicts that have opportunity to enable young people to independently develop their potentials and realize their interests and needs. The subject of this research is management of the process of pedagogical mediation among peers.

Mediation - pedagogical mediation as a process that is very important to be implemented in the educational process, especially peer mediation, which would provide us secure schools. By introducing this process, training the teaching staff and student training, it provides peace, security and in particular non-violent conflict resolution, non-violent communication which is very important.

The process of pedagogical mediation teaches all the factors in the school how to communicate with each other, which language to use, encourages the maturation of a new one a way of thinking and of understanding. This process is very important because it contributes building trusted interpersonal relationships that contributes much in terms of non-violent conflict resolution, successful and productive communication, improving the school climate and improving the educational process.

Rapid technological development and globalization in general, as well sociopolitical changes in recent decades have influenced the dynamics of social living, but also the change of the system of values. Researching confirms the presence of various types of violence in the school environment .

The need for reorganizing a longer time program in schools, unlike the programs that have so far often been applied, did not lead us to good outcomes beside designing the project itself to approach this issue. In fact, our idea was for teachers and students in secondary schools to get acquainted with the notion of conflict, the ways to overcome it, but also the young ones to encourage to independently solve the problems they face in everyday life.

In 2010, UNICEF, in cooperation with the Ministry of Education and Science, launched the program "Prevention and reduction of violence in schools", strengthening the capacities of the education system for effective action and in order to reduce violence in schools. The program supports the creation of school-based prevention programs and intervention programs and protocols in schools. The program provides trainings for effective action and reduction of violence in schools.

As an additional support, the Project Strategies and Child-Friendly Schools aims to promote peace, freedom, tolerance, dignity, equality, solidarity, physical and mental health and well-being.

Mediation among school peers is a one of the aspects of pedagogical ways for understanding and solving the conflict between middle-aged people, activities that have been supported by MON until 2012, as well as support of OEBS had a number of activities of multiethnic character. We should ask ourselves does this model, as a measure of prevention, achieves its first goal, namely reducing violence and creating a safe and harmonious school environment?!

\section{NONVIOLENT COMMUNICATION}


Communication is a basic human activity. Difficulties in communicating with others can be a cause of fear, frustration, or even violence. The model of non-violent communication is a model of sarcastic speaking, which comes from dying out of service, rising, and bonding. This was a provision for the feeling of being " ChildFriendly Schools " -

themselves, others and quality intercommunication. The model is being designed by Marshall B. Rosenberg (Rosenberg, 2002:27).

The essence of this model is to send correct and right message from the people who talk to each other. The message we are sending is always about the one who speaks for itself, and its friend, and the same time we are empathic with ourselves: we connect with our own emotions and needs as well as for what we are seeking only when talking about ourselves. We express our personal feelings about what someone else has done or said. In this way, we prevent the other person to whom we are addressing our opinion to feel that he is directly attacked.

\section{MEDIATION AS A MODEL OF PEDAGOGICAL MEDIATION}

Pedagogical mediation is a way of resolving conflicts and overcoming misunderstandings in which, neutrally, third party appears as a mediator, i.e. mediator between opposite parties. The aim of the methodology is to approach the conflict in a constructive way and to find a common solution that is compatible (Triklić, 2003:161).

Adoption of pedagogical mediation as a communication concept in our schools would mean a lot for our entire educational system, a relaxed environment, a good school climate allowing us to acquire knowledge and skills that contribute to personal growth and development of students, supporting teachers and achieving all the goals and tasks provided by the teaching plans and programs.

In the Republic of Macedonia pedagogical mediation, is legally applied to the legal system to the extent that the system of education is implemented through the project activities conducted in the school or in the course of the lessons included in the teaching process.

If we come to the situation of a misunderstanding of conflict in schools, teachers attend to make such meetings as they are recommended to mediators. Mediation is a voluntary process, the parties to the conflict themselves report the mediator that they are ready to sit down to solve the problem. The role of the mediator is to support them all the time while the process lasts and encourage them to solve the problem and talk about it. The type of mediation used in peer mediation is called the Facilitative Mediation, this kind of mediation is known in the world as Transformative and Evaluative Mediation. I will try to briefly describe these approaches and how does the whole process of mediation looks like , step by step, that will be worked out in the next lines.

\section{RESEARCH METHODOLOGY}




\section{Problem of research}

As the national strategy for conflict reduction proposes mediation as a communication model for solving and preventing violence, the question arises as to the problem of this research: Does this communication model successful set its goal? Is it accepted as a model for conflict resolution and is it applied in everyday school life?! . By examining the attitudes of the students for whom this communication model is intended, can the strengths and weaknesses of the process of peer education be identified? This is a question that can be answered at the end of this study, because it poses a dilemma whether this communication model is compatible with the adolescent population? And is the purpose of this communication model to raise awareness of the moral education of the youth for recognition and rational behavior in their mutual relations?!

\section{Subject of the research}

The subject of this research is an examination of students' attitudes and their acceptance of the process of mediation and also detection of positive effects of conflict resolution and preventing violent behavior. The relevant data will benefit from the direct participants in the educational process, the students and teachers involved and trained in the running of the mediation process.

\section{The aim and character of the research}

The purpose of this research is to define the positive effects of mediation as a pedagogical model within the improvement of intercommunication processes among all concerned participants in the educational process in secondary schools. The effects of a pedagogical concept in this research are perceived through its impact on the overall school atmosphere and the reduction of the level of violence in secondary schools in the multiethnic environment in the Republic of Macedonia.

\section{Research hypotheses}

Our research is considered to prove that pedagogical interventions among peers treated in the project "Mediation of Teachers" positively influenced on the human relations in secondary schools, by getting the communication of all system on the highest levels and ensuring a safe teaching and learning environment.

\section{Research methods and techniques}

In the research, several methods are used which provide high quality knowledge, such as: analysis (structural and content), synthesis, description, induction generalizations.

\section{In this research we used survey as research technique}


In this research, we used two questionnaires: Questioner for examining students 'attitudes and opinions over the teacher attitudes.

The first part of the questionnaires is intended to obtain information on the general data of the users, and this questionnaire is closed questionnaire type. The second questionnaire is formed of the questions: closed type, open type, combination of open and open source, part of the questions in the form of scales of assessment and some of them have the character of check-lists.

\section{Research population and the sample of research}

Sample of the municipality - Mediation among peers is realized in 5 (five) municipalities with multiethnic composition on the territory of the Republic of Macedonia, in Tetovo, Gostivar, Kicevo, Struga and Prilep.

The examination of secondary schools - Mediation between peers is realized in secondary schools, represented in secondary education, as follows: grammar school and secondary vocational in the mentioned municipalities. Mediation between peers is conducted in a total of 17 (seventies) secondary schools, as follows: 5 (five) secondary schools in Tetovo, 5 (five) secondary schools in Prilep, 3 (three) secondary schools are enrolled in Gostivar, Kicevo participates with 2 (two) secondary schools, as well as Struga with 2 (two) secondary schools.

Participants (pupils) - As a special sub-sample in the process of this research, the students will be represented every year, i.e. from the first, second, third and fourth years, from each secondary project school. From each parallel are determined by three students, who are directly included in the training and activities. In total, 110 students are trained in each academic year. In the realization of the activities and trainings were included between 500 and 560 pupils (in the period from 2012 to 2014). In the research, a total of 200 students are interviewed.

Examples of applications - As well as the respondents who will be interviewed, they will be interviewed by part of the teachers who have applied and trained with the mediation process among the peers, from all the five municipalities mentioned above, and in that period from 2012 to 2014, about 200 teachers have been trained, which means that they are respondents. There are a total of 100 teachers who are going to be examined and it is going to be done by 20 trained teachers.

\section{Data processing}

In this research we applied a quantitative and a qualitative processing of data. In the quantitative analysis within cognitive statistics we applied descriptive and inferential statistics, as well: we determine for the frequency distribution, percentage and graphical representation of frequencies, linear regression and t-test (data obtained from the closed type questionnaire). For this kind of processing of data the Statistical System for Social Sciences (IBM SPSS 20.0) is used. Other data from other part of questionnaire are obtained from open character questions and they are qualitatively processed and analyzed.

\section{Conclusion insights - Pupils}


About $90 \%$ of students surveyed think that the project "mediation among peers" has a positive impact on the process of communication in the educational process in the school, compared to $10 \%$ of the respondents in the project, "mediation of the interviewers", and the newcomers are not aware of the increased level of communication and communication between all involved entities in this process.

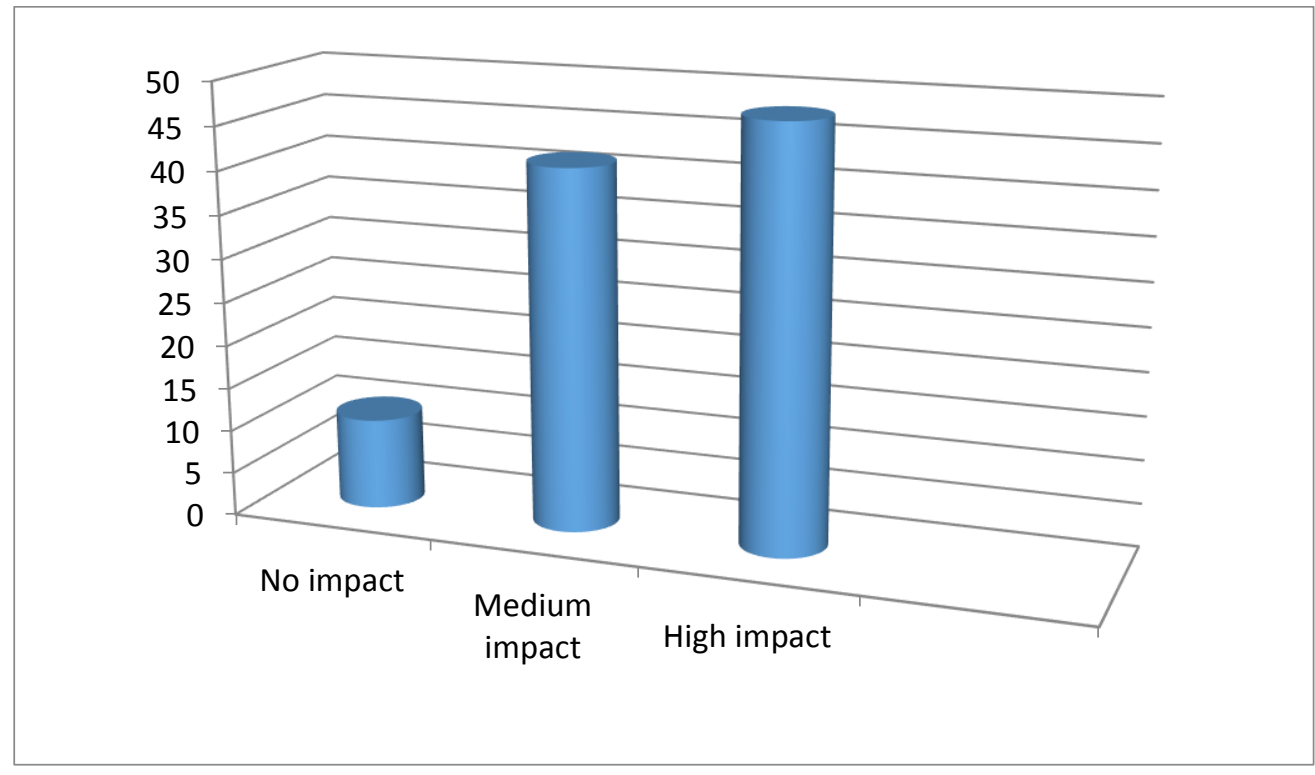

Chart 1. Does the mediation process have a positive effect on improving communication and collaborating in order to help pupils?

In the process of the activities of "mediation among peers", several workshops were conducted in which the students were trained in the ways and the nature of harassment, and it is worth mentioning some of those workshops that according to the students' repatriation were highly ranking The following were highly ranked by students: How do you see me, Conflict and peace, Mediator in the mirror, We are listening each other, How to tell you, Mediator at work, Roles and responsibilities. After analyzing the data, the first place takes Mediator at work as the most successful, after it goes Conflict and peace, and then How do you see me, and so on. These three mentioned workshops are interesting to note that they have a joint activity in the way that they allow the students to practice their own ways of resolving some $90 \%$ of the deterioration of their equipment, it is probably that the students can prove or be at the center of the attention! After processing the rest of the data from the survey, it results that over $86 \%$ of the students who study and work on the activity of the project, "mediation among peers", are generally satisfied with the process and the project opposite result is to the level of $12 \%$ which is not satisfied with the project activities itself. 


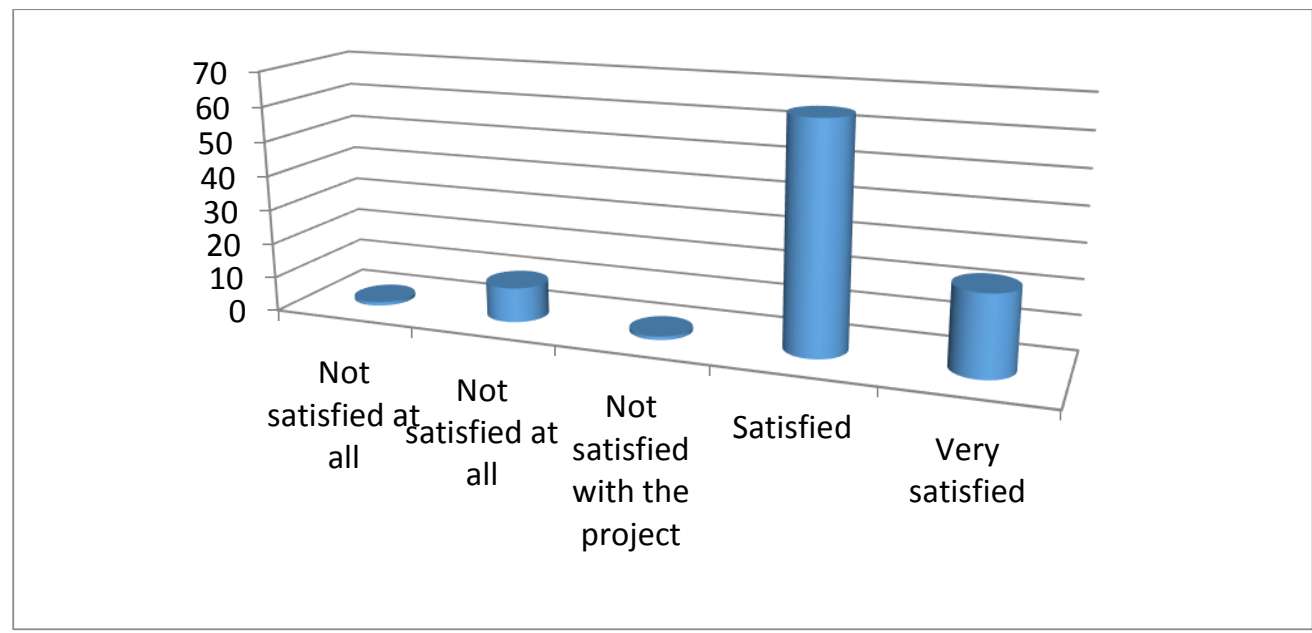

Chart 2. Are you satisfied with mediation activities for peers?

The following analysis also points out the fact that the main hypothesis of the research is confirmed and it is concluded that the activities of the project "peer mediation" realized in secondary schools play a role in improving the pedagogical and generally healthy communication between the subjects involved in the educational process $.97 \%$ of the respondents agree that the project proposal is not enough to improve the combinational relations within the school environment, but slightly $3 \%$ who disagreed the positive impact of the project on communication in general in the educational process.

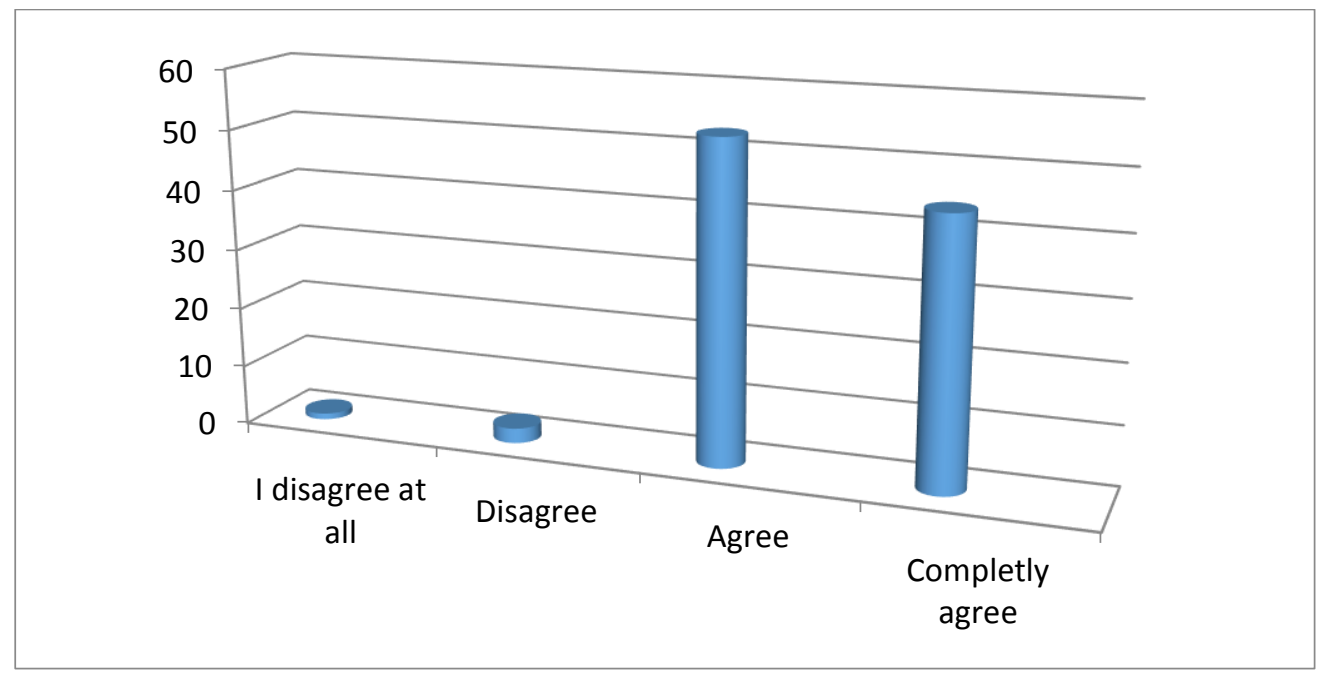

Chart 3. The role of this project is very important for the improvement of intercommunication in the school community. 
According to the summarized data (Table 6. and Chart 9.), the first question from the third part of the survey is "Does the realized activities develop positive values?", pointing out several psycho-social values as alternatives that can be ranked (after data processing) by nonviolent behavior, tolerance, respect, responsibility, help, democracy in a hierarchy from the most rounded to less encircled. These psychological and social values of the students, who are sufficient, very and fully develop their own projects, and they are more than $75 \%$ versus $24 \%$ who think that the above mentioned values are not developed with the activities of the project "peer mediation", the expected results are that approximately $98 \%$ of students use something learned from everyday life $57 \%$ sometimes and $42 \%$ always versus all this $1.5 \%$ that never apply. We conclude that there is a difference between the attitudes of students about the impact of the project "peer mediation" in improving the overall communication in the school system between schools, and it is also concluded that there is no difference in the attitudes of students in cities for recognizing the violence and between attitudes towards the development of positive values.

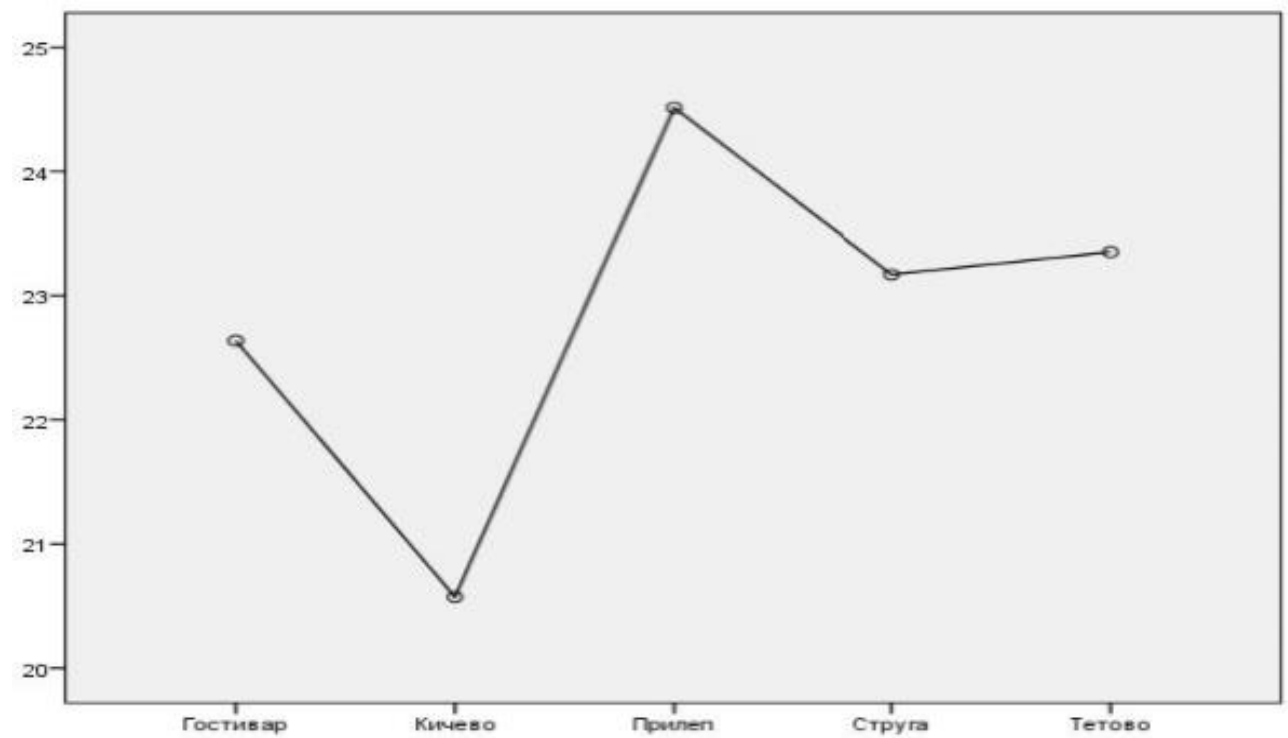

Chart 4. The level of influence of mediation according to the city 


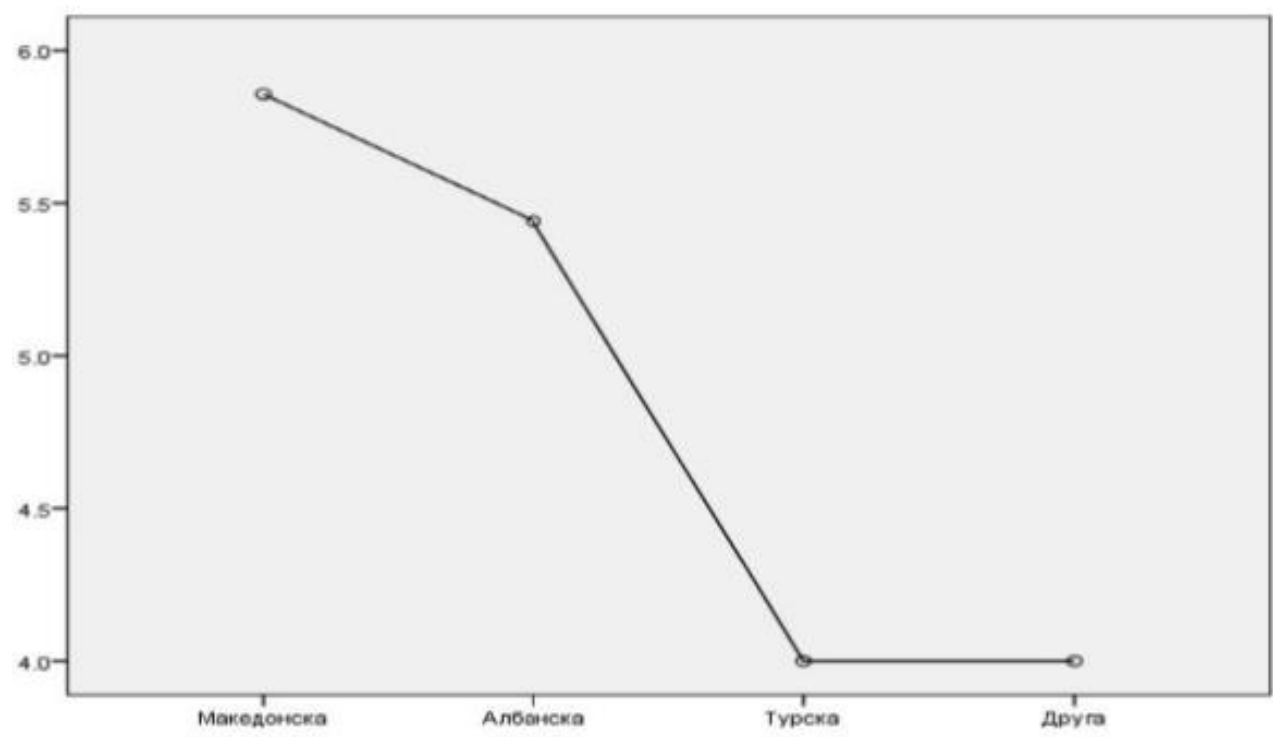

Chart 5.The level of recognition of violence according to the nationality

\section{CONCLUDING OBSERVATIONS - TEACHERS}

The result of teachers' expressed satisfaction with the implementation of the project "peer mediation" in secondary schools corresponds with the percentages of the surveyed students with about $90 \%$ satisfied with the opposite $10 \%$ dissatisfied, also data that indicates and confirms the success of the project itself.

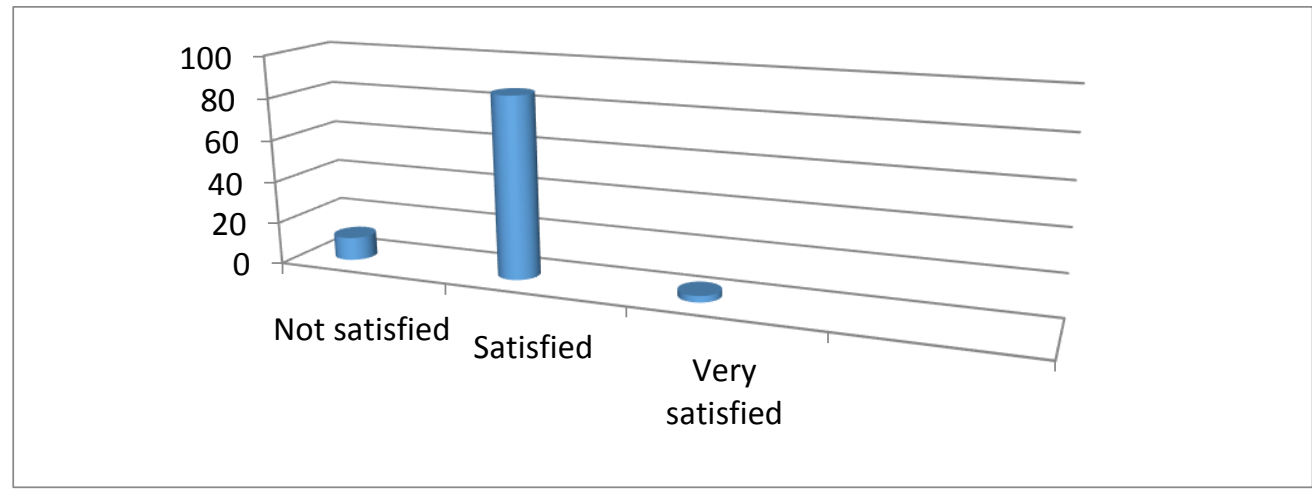

Chart 6. What is the level of your satisfaction with the mediation program between peers? 
Teachers answer that the project has a positive influence on the communication relations between all subjects in the educational process itself, and that $86 \%$ of the teachers agree with this statement compared to $14 \%$ who disagree. From the nonviolent behavior, tolerance, respect, accountability, help, democracy, and the hierarchy, the disagreement is rounded to a lesser degree. The psycho-social that were mentioned before are values according to the teachers who think that this project is developed and successful sufficiently ii 53\% (75\% students) versus $47 \%$ (24\% students) that these above mentioned values are not developed with the activities of the project, "peer mediation". The difference in these percentages in this attitude among students and teachers is probably a consequence of the expertise and competence of the teachers, more comprehensively considering the way and the process of developing positive values among the person.

\section{LITERATURE}

1. ROZENBERG,M. (2002): Jezik saosećanja (Nenasilnička komunikacija).Beograd: Zavod za udžbenike i nastavna sredstva стр.27

2. Trikić, Z. I dr. (2003): Vršnjačka medijacija - od svađe slađe. Beograd: Nemačka organizacija za tehničku saradnju (GTZ) GmbH cтp.161

3. Violence against Children, United Nations Secretary-General's Study, http://www.unviolencestudy.org/

4. ' 'Училиште по мерка на детето' - УНИЦЕФ http://umd.gov.mk/shtoe.aspx

5. http://www.nuub.mk/dmdocuments/ZbornikKonflikti.pdf

\section{RESUME}

Mediation - Mediation as a pedagogical process is very important to be implemented in the educational process especially peer mediation, that could be provided in front of safe schools. By implementing this model, training of teachers and the training of students we provide peace, security and essential would be non-violent conflict resolution, non-violent communication. Today, nonviolent communication is very important because the extreme number of superficial violence. State has to protect its youngest citizens by implementing these kind of projects. 